\title{
Adoption of internet banking in Bosnia and Herzegovina
}

\author{
Admel Husejinovic ${ }^{1 *}$, Mirela Husejinović ${ }^{2}$ \\ ${ }^{1}$ Central Bank of Bosnia and Herzegovina, Bosnia \\ ${ }^{2}$ Ziraat Bank BH dd, Bosnia
}

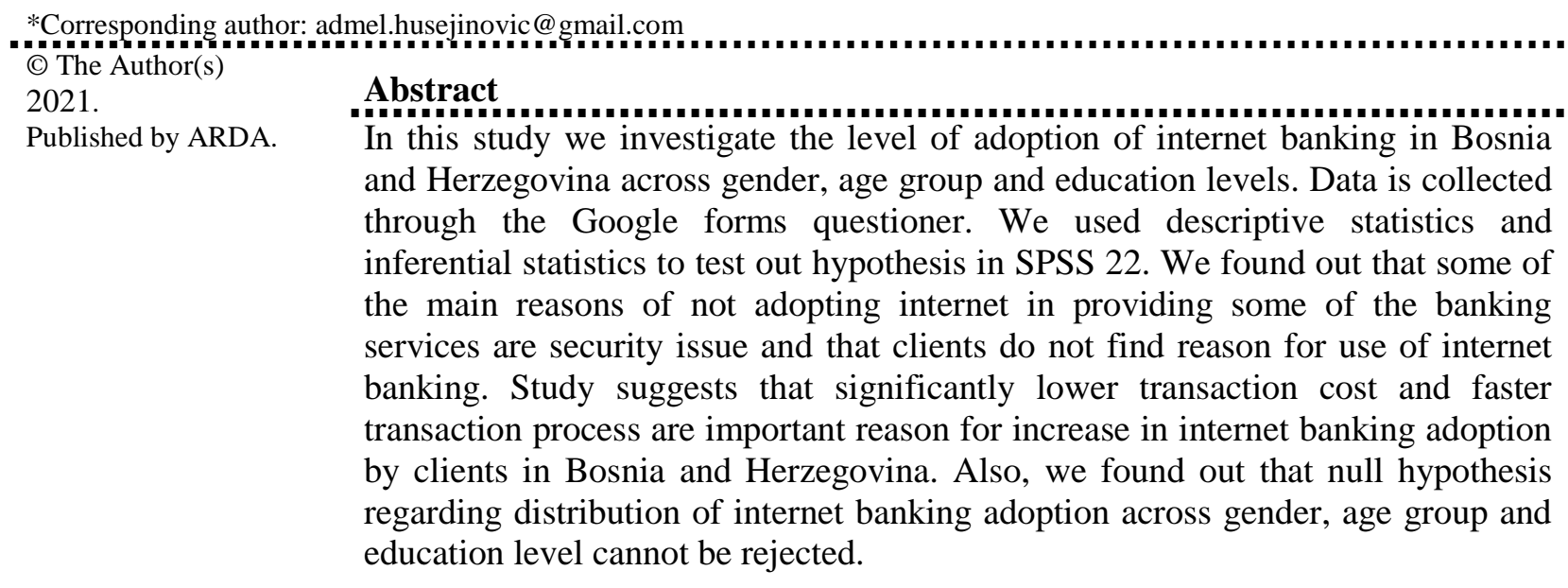

Keywords: Internet banking, Adoption, Gender, Education level, Age groups

\section{Introduction}

As in many successful companies and banks, there is a trend of business globalization, which means that banks find new, more modern and at the same time more efficient ways of placing and distributing their products and services. It is very important to find the optimal combination of distribution channels so that the service is delivered to clients in the fastest and most effective and efficient way, with expected and perceived quality [1]. This tendency is especially emphasized in the retail business of the so-called retail banking, where distribution channels play a very important role in providing better service and user experience. In order for banks to meet all the requirements of their clients and new trends, they rely heavily on innovations in information and communication technology [2].

Internet banking or e-banking represents automated delivery of banking services to clients via electronic communication channels. Clients of banks and financial institutions are allowed access to personal accounts and conducting financial transactions through a public, private networks or the Internet. Customers can accomplish financial transactions using computers, ATMs, or mobile phones. One of the most commonly used forms of e-banking is online or Internet banking that can be defined as an electronic payment system that enables clients of a bank or a financial institution to realize financial transactions through a web institution [3]. Electronic banking is a very important channel that SMEs are increasingly using, primarily because of the savings they are making in this way, especially if they have many similar or identical transactions. Internet, like other non-physical indirect channels, provides 24/7 access to financial services, whereby, unlike the use of ATMs, the Internet allows the use of services without leaving the physical space in which the user is located [4]. In this paper, we investigate the determinants of acceptance of the use of internet banking in Bosnia and Herzegovina. We explore the level of significance across genders, age groups and education levels. We must note that research on this topic in Bosnia and Herzegovina is still few [5]-[8], so this paper could be a contribution to the modest literature on this topic, as well as an indicator to bank managers in shaping market strategy when it comes to modern distribution channels.

This work is licensed under a Creative Commons Attribution License (https://creativecommons.org/licenses/by/4.0/ ) that allows others to share and adapt the material for any purpose (even commercially), in any medium with an acknowledgement of the work's authorship and initial publication in this journal. 


\subsection{Payment instruments in e-banking used in Bosnia and Herzegovina}

Payment instruments are instruments that enable clients to transfer funds. Payment instruments in electronic banking represent different forms of electronic money. Electronic or digital money is defined as "specific monetary information transmitted electronically between transactions in real time". Electronic money is "the digital equivalent of a cache, stored on an electronic device or on a remote server" [9]. The basic division of electronic money is into: Card based electronic money; Electronic money based on software that enables the transfer of money through an electronic network. Payment cards are primarily used by customers to withdraw cash from ATMs, cashless payment at POS machines, online payment, etc. Payment cards are usually divided into 4 groups.

Credit cards are a cashless payment instrument that also serves as a convenient means of short-term consumer credit. The basis of card issuance is account cover, approved credit, or credit rating of the cardholder. There are several types of credit cards on the market today. A revolving credit card is a card with a renewable credit limit. Banks approve a credit card credit limit that customers can use to buy and pay for merchandise or to withdraw cash based on the customer's creditworthiness. The client is obliged to settle a certain percentage of the debt used each month (5 or 10\%), while the regular interest is charged on the rest of the debt. Charge credit cards which, like those of previous credit cards, are granted a credit limit, but with the difference that the used limit is repaid in one installment. The co-branding card issued by the bank to its clients in cooperation with the partner company, thus integrating the offers of both institutions to offer the clients the best benefits such as points, discounts, gifts, bonuses, and thus is rewarded for completing the transaction and encourages more frequent use of the card.

Debit card are type of cards that banks issue based on various deposit accounts. The client uses his debit card funds and spends as much money as he has on the account. They are usually used for the inflow of regular funds such as salary, pension, etc. These cards can also be used for cashless payment (at retail outlets and online), as well as for cash withdrawals at ATMs and within bank branches.

Prepaid cards are payment cards that are not usually linked to a credit or debit account with a bank. These are prepaid cards that can be pre-denominated in cash or pay a certain amount that can later be used in cashless terms.

Cash cards are cards exclusively used to withdraw cash at ATMs or at bank branches.

\subsection{Adoption of Internet banking in Bosnia and Herzegovina 2009-2017}

The number of Internet banking users in Bosnia and Herzegovina has been on the rise in the last 10 years, according to data from the Central Bank. Today, in all commercial banks in $\mathrm{BH}$, we can find an offer of alternative distribution channels services such as e-banking, m-banking, SMS banking, ATM and POS devices, etc. Table presents the number of users of electronic banking of legal entities and individual users in the period from 2009 to 2017 in Bosnia and Herzegovina.

Table 1. Number of clients using electronic banking services 2009-2017

$\begin{array}{cc}\text { Year } & \text { Number of clients using electronic banking } \\ \text { services } & \begin{array}{c}\text { Number of banks offering e-banking } \\ \text { services }\end{array}\end{array}$

\begin{tabular}{lcccc} 
& legal entities & individuals & Total & \\
\hline $\mathbf{2 0 0 9}$ & 19.000 & 33.000 & $\mathbf{5 2 . 0 0 0}$ & 28 \\
$\mathbf{2 0 1 0}$ & 19.257 & 48.545 & $\mathbf{6 7 . 8 0 2}$ & 27 \\
$\mathbf{2 0 1 1}$ & 23.865 & 70.474 & $\mathbf{9 4 . 3 3 9}$ & 27 \\
$\mathbf{2 0 1 2}$ & 29.599 & 96.041 & $\mathbf{1 2 5 . 6 4 0}$ & 27 \\
$\mathbf{2 0 1 3}$ & 32.156 & 122.522 & $\mathbf{1 5 4 . 6 7 8}$ & 28 \\
$\mathbf{2 0 1 4}$ & 37.974 & 175.588 & $\mathbf{2 1 3 . 5 6 2}$ & 25 \\
$\mathbf{2 0 1 5}$ & 44.802 & 269.975 & $\mathbf{3 1 4 . 7 7 7}$ & All banks \\
$\mathbf{2 0 1 6}$ & 48.053 & 335.708 & $\mathbf{3 8 3 . 7 6 1}$ & All banks \\
$\mathbf{2 0 1 7}$ & 64.961 & 425.898 & $\mathbf{4 9 0 . 8 5 9}$ & All banks \\
\hline
\end{tabular}

Source: [10] 
All banks in BH offer Internet banking or electronic banking. The data show a marked increase in the number of clients using these services. This type of service in 2017 covered a total of 490,859 users, while in 2016 there were a total of 383,761 entities that used this service. Of the total number of Internet users 64,961 are legal entities and 425,898 individuals in 2017. Compared to the previous year, the number of individual users of Internet banking users increased from 335,708 to 425,898 , or by $27 \%$. Business entities recorded a $35 \%$ increase over the previous year, where the number of Internet banking users rose from 48,053 in 2016 to 64,961 in 2017.

On the other hand, according to the official reports of the Banking Agency of the Federation of Bosnia and Herzegovina and the Banking Agency of Republic Srpska, there has been a significant reduction in the number of organizational units of banks in both entities, as well as the fall in the number of employees in the banking sector between 2008 and 2017.

Table 2. Number of organizational units and number of employees in the banking sector in the period from 2008 to 2017

\begin{tabular}{|c|c|c|c|c|c|c|c|c|}
\hline \multirow[t]{2}{*}{ Year } & \multicolumn{4}{|c|}{ Total number of organizational units } & \multirow{2}{*}{\multicolumn{2}{|c|}{$\begin{array}{l}\text { Total number } \\
\text { banking sector } \\
\text { FB\&H }\end{array}$}} & \multirow{2}{*}{$\begin{array}{l}\text { employe } \\
\text { RS }\end{array}$} & \multirow[t]{2}{*}{ in the } \\
\hline & FB\&H & & $\mathbf{R S}$ & & & & & \\
\hline 2008 & 650 & & 384 & & 7.997 & & 3.063 & \\
\hline 2009 & 635 & $-2 \%$ & 347 & $-10 \%$ & 7.656 & $-4 \%$ & 2.939 & $-4 \%$ \\
\hline 2010 & 600 & $-6 \%$ & 355 & $2 \%$ & 7.388 & $-4 \%$ & 2.933 & $0 \%$ \\
\hline 2011 & 612 & $2 \%$ & 360 & $1 \%$ & 7.369 & $0 \%$ & 2.993 & $2 \%$ \\
\hline 2012 & 585 & $-4 \%$ & 367 & $2 \%$ & 7.130 & $-3 \%$ & 3.206 & $7 \%$ \\
\hline 2013 & 580 & $-1 \%$ & 387 & $5 \%$ & 7.051 & $-1 \%$ & 3.306 & $3 \%$ \\
\hline 2014 & 571 & $-2 \%$ & 328 & $-15 \%$ & 6.960 & $-1 \%$ & 3.213 & $-3 \%$ \\
\hline 2015 & 557 & $-2 \%$ & 336 & $2 \%$ & 6.683 & $-4 \%$ & 3.236 & $1 \%$ \\
\hline 2016 & 551 & $-1 \%$ & 298 & $-11 \%$ & 6.615 & $-1 \%$ & 2.974 & $-8 \%$ \\
\hline 2017 & 533 & $-3 \%$ & 293 & $-2 \%$ & 6.655 & $1 \%$ & 2.917 & $-2 \%$ \\
\hline
\end{tabular}

Source: [11]

The data indicating the growth in the number of banks in BH that offer Internet banking or some kind of electronic banking, as well as the growth of the number of users (individuals and legal entities) who use some of the electronic banking services on the one hand, and a decrease in the number of branches and the number of employees in banks, on the other hand, leads us to the conclusion that commercial banks in $\mathrm{BH}$ have recognized all the advantages of modern distribution channels that they bring to the bank, and for this reason, with the expanded offer of services through electronic banking and other services, part of the business has been redirected precisely through these distribution channels.

\section{Literature review}

Several studies were conducted regarding internet banking adoption of customer in some countries [12]-[16]. Among the most common factors investigated are gender, age, and education level.

- Using Logistic Regression concluded that education level and income level does affect e-banking use in Bosnia and Herzegovina based on survey results [8].

- Investigate internet banking adoption in Oman. Major findings suggest that security and data confidentiality issues are a key barrier in adoption. Lack of top management support was found to be a preventing factor in adoption. They conclude that banks in the Arab Gulf region have been 'quite slow' in process of introducing e-banking services [17].

- Investigating 40 bank customers in Nigeria [15] study demonstrates that Nigerian customers lack trust in internet banking because of security subject, bank repute, information technology and trust in institutional system [18].

- Devi et al investigated internet banking adoption in Mauritius. In their study they find that level of education and income are the most important determinants influencing adoption of internet banking. 
- Malhotra et al investigated factors affecting internet banking adoption in India. Research was conducted using Partial Least Squares (PLS) technique on customers of 150 banks in India [19].

- Sarkane et al developed internet banking success model based on factors: easy to use, supposed risk, trust and supposed usefulness. Study shed that in both countries supposed risk was the most important factor affecting internet baking adoption in Lithuania and Latvia [20].

- Ahmet Em and Phin Gs investigated how demographic characteristics, social factors, and consumer perceptions and attitudes influence internet banking adoption in Malaysia. Overall, it showed that social factors influence adoption of internet banking [21].

- Vats and Maheshware investigated customer trust on the adoption of internet banking. Findings suggest that there is a significant influence of trust on customer's adoption of internet banking. Also, there is no difference of customers adoption across gender difference [22].

\section{Methodology}

Our study's data vas conducted using survey on internet banking use in Bosnia and Herzegovina. The survey was conducted through an online survey questionnaire (Google Forms) distributed via social networks or email, as well as by direct interviewing with a questionnaire for people who do not use the Internet or do not have enough internet experience. The interview was conducted in the period from 03.09.2018. until 20.10.2018. among the population of the city of Sarajevo. Given that electronic banking services are linked to the accounts of all adult clients in banks (working age population, students, pensioners), our respondents belong to the population aged 18 to 70 years.

The survey included 114 respondents:

- 2 examinees in the age group of up to 20 years; 1 male respondent and 1 female respondent were included.

- $\quad 31$ respondents in the age group of 21-30 years; 8 males and 23 female respondents were enrolled.

- $\quad 54$ respondents in the age group of 31 to 40 years; There were 22 male respondents and 32 female respondents.

- 14 respondents in the age group of 41 to 50 years; 2 male and 12 female respondents were enrolled.

- 8 respondents in the age group of 51 to 60 years; There were 3 male respondents and 5 female examinees.

- 3 respondents in the age group over 60 years; There were 3 male respondents and 0 female respondents.

The results show that most respondents use Internet banking, of which 95 or $83 \%$ use internet banking services of 19 respondents said they do not use Internet banking. If we observe the gender structure, we notice that women use Internet banking more, with 76 women, 64 of them responding positively.

\section{Hypothesis}

H1: There is no difference of internet banking adoption across customer gender.

$\mathrm{H} 2$ : There is no difference of internet banking adoption across customer age groups.

H3: There is no difference of internet banking adoption across customer education level.

H4: Education level and main reason for choosing internet bank are independent.

Nonparametric test - Independent Samples - Che Square Test was applied to measure the difference of Customer's adoption of internet banking across gender. Nonparametric test - Independent Samples - Mann Whitney U Test was applied to measure the distribution of Age groups and education levels across the categories of Internet banking users. Nonparametric test - Independent Samples Kruskal-Wallis Test for testing difference of reasons of choosing internet banking bank across education levels.

\section{Results}

As we can see from the table below there are 31 male and 65 female internet banking users. There is also 7 male and 12 female internet banking non-users. 
Table 3. Internet banking user vs. gender crosstabulation

Crosstabulation

Count

\begin{tabular}{|c|c|c|c|c|}
\hline & \multicolumn{2}{|c|}{ Gender } & \multirow[b]{2}{*}{ Total } \\
\hline & & Male & Female & \\
\hline \multirow[t]{2}{*}{ Internet banking user } & YES & 3 & 65 & 96 \\
\hline & $\mathrm{NO}$ & r & 12 & 19 \\
\hline Total & & 38 & 77 & 115 \\
\hline
\end{tabular}

Source: Autor's, using SPSS 22

We have tested H_0: There is no difference of internet banking adoption across customers' gender. And alternative hypothesis H_a: There is difference of internet banking adoption across gender. At the significance level of 0,05 using Pearson Chi-Square Test with p-value equal to 0,700 we cannot reject $\mathrm{H}_{-} 0$ hypothesis. As p-value is not less than 0,05 we conclude that Internet banking user status and person's gender are independent of each other.

Table 4. Che-Square Test for two nominal variables

Chi-Square Tests

\begin{tabular}{|c|c|c|c|c|c|}
\hline & Value & $\mathrm{df}$ & $\begin{array}{l}\text { Asymp. Sig. } \\
\text { (2-sided) }\end{array}$ & $\begin{array}{l}\text { Exact Sig. (2- } \\
\text { sided) }\end{array}$ & $\begin{array}{l}\text { Exact Sig. (1- } \\
\text { sided) }\end{array}$ \\
\hline Pearson Chi-Square & $.148^{\mathrm{a}}$ & 1 & $\overline{.700}$ & \multirow{7}{*}{.791} & \multirow{7}{*}{.445} \\
\hline Continuity Correction ${ }^{\mathrm{b}}$ & .014 & 1 & .906 & & \\
\hline Likelihood Ratio & .146 & 1 & .702 & & \\
\hline Fisher's Exact Test & & & & & \\
\hline Linear-by-Linear & 147 & 1 & 701 & & \\
\hline Association & & & & & \\
\hline $\mathrm{N}$ of Valid Cases & 115 & & & & \\
\hline
\end{tabular}

a. 0 cells $(0.0 \%)$ have expected count less than 5 . The minimum expected count is 6.28 .

b. Computed only for a $2 \times 2$ table

Source: Author's, using SPSS 22

As we can see from the table 5 below there are 1 up to 20 years old, 27 from 21 to 30 years old, 49 from 31 to 40 years old, 11 from 41 to 50 years old, 6 from 51 to 60 years old and 2 over 60 years old internet banking users. There is also 5 from 21 to 30 years old, 8 from 31 to 40 years old, 3 from 41 to 50 years old, 2 from 51 to 60 years old and 1 over 60 years old internet banking non-users.

Table 5. Internet banking users vs. age group crosstabulation

\section{Crosstab}

Count

\begin{tabular}{|ll|l|l|l|}
\hline & & \multicolumn{2}{|l|}{ Internet banking user? } & \multirow{2}{*}{ Total } \\
\cline { 3 - 5 } & & Yes & No & 1 \\
\hline Customer Age & Up to 20 years & 1 & 0 & 32 \\
& From 21 to 30 years old & 27 & 5 & 57 \\
& From 31 to 40 years old & 49 & 8 & 14 \\
& From 41 to 50 years old & 11 & 3 & 8 \\
& From 51 to 60 years & 6 & 2 & 3 \\
Total & Over 60 years & 2 & 1 & 115 \\
\hline
\end{tabular}

Source: Author's, using SPSS 22 
We have tested $H_{0}$ : There is no difference of internet banking adoption across customer age group. And alternativ hypothesis $H_{a}$ : There is difference of internet banking adoption accross age group. At the significance level of 0,05 using Independent Sample Mann-White U Test with p-value equal to 0,392 we can not reject $H_{0}$ hypothesis. As p-value is not less then 0,05 we conclude that there is no difference of internet banking adoption across age groups.

\section{Hypothesis Test Summary}

\begin{tabular}{|c|c|c|c|c|}
\hline & Null Hypothesis & Test & Sig. & Decision \\
\hline 1 & $\begin{array}{l}\text { The distribution of Age Group is the } \\
\text { same across categories of Internet } \\
\text { Bankig User?. }\end{array}$ & $\begin{array}{l}\text { Independent- } \\
\text { Samples } \\
\text { Mann- } \\
\text { Whitney U } \\
\text { Test }\end{array}$ & 392 & $\begin{array}{l}\text { Retain the } \\
\text { null } \\
\text { hypothesis. }\end{array}$ \\
\hline
\end{tabular}

Asymptotic significances are displayed. The significance level is .05 .

Figure 1. Independent Samples Mann-White U Test for non-parametric test age group across internet banking users. Source: Author's, using SPSS 22

As we can see from the table below there are 53 university, 21 Master or $\mathrm{PhD}, 19$ high school education level internet banking users. There is also 7 university, 2 Master or $\mathrm{PhD}$ and 7 high school education level internet banking non-users.

Table 6. Internet banking users vs. education level crosstabulation

\section{Crosstab}

Count

\begin{tabular}{|cc|l|l|l|l|}
\hline \multirow{2}{*}{} & \multicolumn{2}{|l|}{ Customers Education Level } & \multirow{2}{*}{ Total } \\
\cline { 3 - 6 } & University & Master or Phd & High School & 93 \\
\hline Internet banking user? & Yes & 53 & 21 & 19 & 16 \\
& No & 7 & 2 & 7 & 109 \\
\hline \multirow{2}{*}{ Total } & 60 & 23 & 26 & \\
\hline
\end{tabular}

Source: Author's, using SPSS 22

We have tested $H_{0}$ : There is no difference of internet banking adoption across customer education level. And alternativ hypothesis $H_{a}$ : There is difference of internet banking adoption accross education level. At the significance level of 0,05 using Independent Sample Mann-White U Test with p-value equal to 0,146 we can not reject $H_{0}$ hypothesis. As p-value is not less then 0,05 we conclude that there is no difference of internet banking adoption across education level.

Hypothesis Test Summary

\begin{tabular}{|clrl|}
\hline \multicolumn{1}{|c|}{ Null Hypothesis } & \multicolumn{1}{c}{ Test } & Sig. & Decision \\
\hline & $\begin{array}{l}\text { Independent- } \\
\text { Samples }\end{array}$ & Retain the \\
$\mathbf{1} \begin{array}{l}\text { The distribution of Education Level } \\
\text { is the same across categories of } \\
\text { Internet Bankig User? }\end{array}$ & $\begin{array}{l}\text { Mann- } \\
\text { Whitney U } \\
\text { Test }\end{array}$ & $146 \begin{array}{l}\text { null } \\
\text { hypothesis. }\end{array}$ \\
\hline
\end{tabular}

Asymptotic significances are displayed. The significance level is .05 .

Figure 2. Independent Samples Mann-White U Test for non-parametric test education level group across internet banking users. Source: Author's, using SPSS 22

Analyzing determinants of adoption of internet banking we find out that security issues and "I have no reason for internet banking account" are most common reason among the others (see Appendix 4). Dominant factors 
affecting not use of internet banking are lower transaction costs, fast transaction realization and access to account balance information (see Appendix 3).

Table 7. Reasons for choosing business bank vs education level crosstabulation

The most important reason for choosing a bank as your internet bank * Education degree Crosstabulation

Count

\begin{tabular}{|c|c|c|c|c|c|}
\hline & \multicolumn{3}{|c|}{ Degree of education } & \multirow[b]{2}{*}{ Total } \\
\hline & & University & Master/PhD & $\begin{array}{r}\text { High } \\
\text { School }\end{array}$ & \\
\hline \multirow[t]{6}{*}{$\begin{array}{l}\text { The most important } \\
\text { reason for choosing a } \\
\text { bank as your internet bank }\end{array}$} & $\begin{array}{l}\text { The bank demanded with a loan that I } \\
\text { take a package of products that } \\
\text { included internet banking }\end{array}$ & 3 & 3 & 6 & 12 \\
\hline & Excellent service offered by this bank & 2 & 1 & 2 & 5 \\
\hline & $\begin{array}{l}\text { I am a bank customer and I use their } \\
\text { other products }\end{array}$ & 38 & 16 & 9 & 63 \\
\hline & At the request of the employer & 1 & 0 & 0 & 1 \\
\hline & $\begin{array}{l}\text { Bank advertisements of their internet } \\
\text { banking applications }\end{array}$ & 5 & 0 & 0 & 5 \\
\hline & Bank's reputation and brand & 5 & 1 & 1 & 7 \\
\hline Total & & 54 & 21 & 18 & 93 \\
\hline
\end{tabular}

Source: Author's, using SPSS 22

The most common reason for choosing business bank for internet banking is „I am a bank customer and I use their other products" with 63 out of 93 listed resons. This reson is represented with 38, 16 and 9 cases accross university, master/PhD and high school levels respectivly (see table 7). Results sugest that clients are loyal to their already choosen bank regardless of internet banking product offer. Bank advertisements of their internet banking products are dominant reson only in 5 out of 93 cases each for the customers with university level of education. Banks that demend internet banking as a package of products including customer loans. This is main reson for 12 out of 93 cases with distribution of 3, 3 and 6 across university, master/PhD and high school respectivly. Bank reputaion, excellent service offered by bank and request of employer are the least represented reasons.

Hypothesis Test Summary

\begin{tabular}{|llll|}
\hline \multicolumn{1}{|c}{ Null Hypothesis } & \multicolumn{1}{c|}{ Test } & Sig. & Decision \\
\hline $\begin{array}{l}\text { The distribution of Najbitniji razlog } \\
\text { odabira banke kao vaše internet } \\
\text { banke is the same across } \\
\text { categories of Stepen obrazovanja. }\end{array}$ & $\begin{array}{l}\text { Independent- } \\
\text { Samples } \\
\text { Kruskal- } \\
\text { Wallis Test }\end{array}$ & $.004 \begin{array}{l}\text { Reject the } \\
\text { null } \\
\text { hypothesis. }\end{array}$ \\
\hline
\end{tabular}

Asymptotic significances are displayed. The significance level is .05 .

Figure 3. Testing education level groups across reasons of choosing bank using Independent Samples Kruskal-Wallis Test. Source: Author's, using SPSS 22

We have tested $H_{0}$ : Education level and main reason for choosing internet bank are independent. And alternativ hypothesis $H_{a}$ : Education levels and reason for choosing internet bank are not independent. At the significance level of 0,05 using Independent Samples Kruskal-Wallis Test with p-value equal to 0,004 we can reject $H_{0}$ hypothesis. As p-value is not less then 0,05 we conclude that there is difference of reason for choosing internet bank across education level. 


\section{Conclusion}

Findings of this study suggest that there is enormous increase in internet banking use in Bosnia and Herzegovina in the last ten years. Many banks reduced e-banking transaction cost to stimulate use of internet banking by clients (see Appendix 2). Many European countries have high level of internet banking use by their population (see Appendix 1) as we can see in our study that there is a trend of increase in use of internet banking in Bosnia and Herzegovina. Result in increase in use of internet banking reduced number of employees and branch offices in Bosnia and Herzegovina. We also investigated reasons of not having opened E-banking account within a bank: "I have no need for Internet banking Account", and "Security issues" are the most common reasons for not having account (see Appendix 3). The reasons of having account with banks are fast transaction processing and transaction costs among the others (see Appendix 4). In this study we investigated distribution of internet banking user by gender, age groups and education levels. We also investigate dependence between customers' reasons for choosing internet banking business bank. We found that there is no difference in gender, age group or education level across internet banking users. We also found that reasons of choose of internet banking business bank and education level groups are not independent.

In this research, a relatively small number of respondents were collected, which is one of the biggest limitations for drawing generic conclusions.

\section{Appendices}

Appendix A. Use of Internet banking in European countries

\begin{tabular}{llllll}
\hline Country / Year & $\mathbf{2 0 1 3}$ & $\mathbf{2 0 1 4}$ & $\mathbf{2 0 1 5}$ & $\mathbf{2 0 1 6}$ & $\mathbf{2 0 1 7}$ \\
\cline { 2 - 6 } & \% of users & \% of users & \% of users & \% of users & \% of users \\
EU (28 countries) & 42 & 44 & 46 & 49 & 51 \\
Austria & 49 & 48 & 51 & 53 & 57 \\
Belgium & 58 & 61 & 62 & 64 & 67 \\
Bulgaria & 5 & 5 & 5 & 4 & 5 \\
Montenegro & $:$ & $:$ & $:$ & $:$ & 4 \\
Czech Republic & 41 & 46 & 48 & 51 & 57 \\
Denmark & 82 & 84 & 85 & 88 & 90 \\
Estonia & 72 & 77 & 81 & 79 & 79 \\
Finland & 84 & 86 & 86 & 86 & 87 \\
France & 58 & 58 & 58 & 59 & 62 \\
Greece & 11 & 13 & 14 & 19 & 25 \\
Netherlands & 82 & 83 & 85 & 85 & 89 \\
Croatia & 23 & 19 & 33 & 38 & 33 \\
Ireland & 46 & 48 & 51 & 52 & 58 \\
Iceland & 87 & 91 & $:$ & $:$ & 93 \\
Italy & 22 & 26 & 28 & 29 & 31 \\
Cyprus & 23 & 24 & 20 & 28 & 28 \\
Latvia & 55 & 57 & 64 & 62 & 61 \\
Lithuania & 46 & 54 & 50 & 54 & 56 \\
Luxembourg & 63 & 67 & 65 & 71 & 76 \\
Hungary & 27 & 31 & 34 & 35 & 38 \\
Macedonia & 6 & 9 & 5 & 9 & 8 \\
Malta & 43 & 45 & 47 & 46 & 49 \\
Norway & 87 & 89 & 90 & 91 & 92 \\
Germany & 47 & 49 & 51 & 53 & 56 \\
Poland & 32 & 33 & 31 & 39 & 40 \\
\hline & & & & & \\
\hline
\end{tabular}




\begin{tabular}{llllll}
\hline Country / Year & $\mathbf{2 0 1 3}$ & $\mathbf{2 0 1 4}$ & $\mathbf{2 0 1 5}$ & $\mathbf{2 0 1 6}$ & $\mathbf{2 0 1 7}$ \\
\hline Portugal & 23 & 25 & 28 & 29 & 31 \\
Romania & 4 & 4 & 5 & 5 & 7 \\
Slovakia & 39 & 41 & 37 & 45 & 51 \\
Slovenia & 32 & 32 & 34 & 35 & 39 \\
Serbia & $:$ & $:$ & 8 & $:$ & 16 \\
Spain & 33 & 37 & 39 & 43 & 46 \\
Sweden & 82 & 82 & 80 & 83 & 86 \\
Switzerland & $:$ & 54 & $:$ & $:$ & 66 \\
Turkey & 11 & 14 & 15 & 18 & 23 \\
United Kingdom & 54 & 57 & 58 & 64 & 68 \\
\hline Source: & & & &
\end{tabular}

Source: [23]

Appendix B. Review of commercial banks' fees for services performed at the counter and through the electronic banking service for individuals

\begin{tabular}{|c|c|c|c|c|c|}
\hline \multirow[t]{2}{*}{ Bank } & \multirow[t]{2}{*}{ Service: } & \multirow{2}{*}{$\begin{array}{l}\text { Intra-bank } \\
\text { transactions }\end{array}$} & \multicolumn{2}{|c|}{ Transactions with other banks } & \multirow{2}{*}{$\begin{array}{l}\text { Conversion } \\
\text { EUR / BAM }\end{array}$} \\
\hline & & & Gyro Clearing & RTGS & \\
\hline \multirow[t]{2}{*}{ UniCredit } & at the counter & $2,00 \mathrm{KM}$ & $2,50 \mathrm{KM}$ & $5,00 \mathrm{KM}$ & $0,25 \%$ \\
\hline & through e-banking & $0,30 \mathrm{KM}$ & $0,60 \mathrm{KM}$ & $1,50 \mathrm{KM}$ & $0,10 \%$ \\
\hline \multirow[t]{2}{*}{ Raiffeisen } & at the counter & $2,20 \mathrm{KM}$ & $2,50 \mathrm{KM}$ & $5,00 \mathrm{KM}$ & $0,75 \%$ \\
\hline & through e-banking & $0,30 \mathrm{KM}$ & $0,60 \mathrm{KM}$ & $3,00 \mathrm{KM}$ & $0,20 \%$ \\
\hline \multirow[t]{2}{*}{ Sparkasse } & at the counter & $1,50 \mathrm{KM}$ & $2,50 \mathrm{KM}$ & $7,00 \mathrm{KM}$ & $0,80 \%$ \\
\hline & through e-banking & $0,00 \mathrm{KM}$ & $0,50 \mathrm{KM}$ & $3,00 \mathrm{KM}$ & $0,50 \%$ \\
\hline \multirow[t]{2}{*}{ Intesa Sanpaolo } & at the counter & $1,00 \mathrm{KM}$ & $2,50 \mathrm{KM}$ & $6,00 \mathrm{KM}$ & $0,80 \%$ \\
\hline & through e-banking & $0,30 \mathrm{KM}$ & $0,60 \mathrm{KM}$ & $3,00 \mathrm{KM}$ & $0,60 \%$ \\
\hline \multirow[t]{2}{*}{ ZiraatBank BH } & at the counter & $1,00 \mathrm{KM}$ & $2,50 \mathrm{KM}$ & $6,00 \mathrm{KM}$ & $0,50 \%$ \\
\hline & through e-banking & $0,40 \mathrm{KM}$ & $0,80 \mathrm{KM}$ & $4,00 \mathrm{KM}$ & $0,10 \%$ \\
\hline \multirow[t]{2}{*}{ Sberbank } & at the counter & $1,50 \mathrm{KM}$ & $2,00 \mathrm{KM}$ & 7,50 KM & $0,75 \%$ \\
\hline & through e-banking & $0,50 \mathrm{KM}$ & $0,60 \mathrm{KM}$ & $3,75 \mathrm{KM}$ & $0,20 \%$ \\
\hline
\end{tabular}

Appendix C. Reasons of Not Having E Banking Account within a Bank

\$ResonOfNotHavingEbankingAccount Frequencies

\begin{tabular}{|c|c|c|c|c|}
\hline & \multicolumn{2}{|c|}{ Responses } & \multirow{2}{*}{$\begin{array}{c}\text { Percent of } \\
\text { Cases }\end{array}$} \\
\hline & & $\mathrm{N}$ & Percent & \\
\hline \multirow[t]{4}{*}{ \$ResonOfNotHavingEbankingAccount } & Q2.NeverHeardOfEbanking & 2 & $8.3 \%$ & $11.1 \%$ \\
\hline & Q2.SecurityIssues & 6 & $25.0 \%$ & $33.3 \%$ \\
\hline & Q2.HaveNoTimeToOpenAnAccount & 4 & $16.7 \%$ & $22.2 \%$ \\
\hline & Q2.HaveNoNeedForEBankingAcc & 12 & $50.0 \%$ & $66.7 \%$ \\
\hline Total & & 24 & $100.0 \%$ & $133.3 \%$ \\
\hline
\end{tabular}

a. Dichotomy group tabulated at value 1 .

Source: Author's, using SPSS 22 
Appendix D. Reason of Use of Internet Banking \$ResonOfUseOfEbanking Frequencies

\begin{tabular}{|ll|r|r|r|}
\hline & & \multicolumn{2}{|c|}{ Responses } & \\
\cline { 3 - 4 } & & $\mathrm{N}$ & \multicolumn{1}{|c|}{ Percent } & Percent of Cases \\
\hline \$ResonOfUseOfEbanking $^{\mathrm{a}}$ & Q3.Curiosity & 10 & $4.2 \%$ & $10.5 \%$ \\
& Q3.TransactionCost & 34 & $14.2 \%$ & $35.8 \%$ \\
& Q3.SecurityIssue & 3 & $1.3 \%$ & $3.2 \%$ \\
& Q3.SavingMoney & 21 & $8.8 \%$ & $22.1 \%$ \\
& Q3.LowerFee & 10 & $4.2 \%$ & $10.5 \%$ \\
& Q3.FasterTrn & 60 & $25.0 \%$ & $63.2 \%$ \\
& Q3.BalanceAccess & 60 & $25.0 \%$ & $63.2 \%$ \\
& Q3.PackageofAccs & 34 & $14.2 \%$ & $35.8 \%$ \\
& Q3.BetterIntRate & 8 & $3.3 \%$ & $8.4 \%$ \\
& & 240 & $100.0 \%$ & $252.6 \%$ \\
\hline
\end{tabular}

a. Dichotomy group tabulated at value 1 .

Source: Author's, using SPSS 22

\section{References}

[1] J.-M. Sahut, 'Quality Management of Internet Banking Services', SSRN Electron. J., pp. 1-10, 2012.

[2] J.-M. Sahut, 'The Impact of ICT and the Internet in Banking'. 05-Feb-2011.

[3] T. Radojevic and D. Radovanovic, 'The impact of electronic banking on offer of financial services', in MIPRO 2010 - 33rd International Convention on Information and Communication Technology, Electronics and Microelectronics, Proceedings, 2010.

[4] V. Babić Hodović, Marketing in banking. Sarajevo: School of Economics and Business Sarajevo, 2012.

[5] I. Zivko, 'Barriers in using e-banking in payment system of Bosnia and Herzegovina', in Annals of DAAAM \& Proceedings, 2005, p. 399+.

[6] M. K. Özlen, 'Perceptions of Online Banking Users in Bosnia and Herzegovina', no. August, pp. 375383, 2013.

[7] N. Makarevic, 'Perceptions towards IT Security in Online Banking: Croatian Clients vs. Clients of Bosnia and Herzegovina', Int. J. Financ. Bank. Stud., vol. 5, no. 1, p. 1, 2016.

[8] K. Kozaric and E. Zunic, 'E-Banking in Bosnia and Herzegovina : Determinants of Acceptance', ICES, pp. 175-187, 2014.

[9] B. Radenković, M. Despotović Zrakić, Z. Bogdanović, D. Barać, and A. Labus, Elektronsko poslovanje. Beograd: Fakultet organizacionih nauka Beograd, 2015.

[10] Central Bank of Bosnia and Herzegovina, 'Search results'. [Online]. Available: https://cbbh.ba/search/results?searchTerm=internet bankarstvo. [Accessed: 28-Jul-2019].

[11] Federal Banking Agency, 'Informations on Banks in Bosnia and Herzegovina on 31.12.2017', Sarajevo, 2018.

[12] P. Vasiliki and P. Spyros, 'Electronic Banking in Greece. The case of Chalkida', Int. J. Financ. Econ. Trade, vol. 2, no. 2, pp. 18-30, 2018.

[13] H. L. Li and M. M. Lai, 'Demographic Differences and Internet Banking Acceptance', MIS Rev. An Int. J., vol. 16, no. 2, pp. 55-92, 2011.

[14] A. Me, 'Empirical Analysis of Retail Customers' Adoption of Internet Banking Services in Nigeria', $J$. Internet Bank. Commer., vol. 22, no. 1, pp. 1-17, 2017.

[15] Popoola N., 'The Effect of Trust in Adoption of Internet Banking: A case study of Nigeria.', Int. J. Econ. Bus. Manag., vol. 1, no. 2, pp. 19-24, 2013.

[16] S. A. Oluyinka, A. N. Endozo, and R. R. Calma, 'A study on the acceptance of internet banking', in ICETC 2018, 2019, no. March 2019, pp. 374-378. 
[17] A. M. S. Khalfan, Y. S. Y. AlRefaei, and M. Al Hajery, 'Factors influencing the adoption of internet banking in Oman: a descriptive case study analysis', Int. J. Financ. Serv. Manag., vol. 1, no. 2/3, p. $155,2006$.

[18] T. Devi Juwaheer, S. Pudaruth, and P. Ramdin, 'Factors influencing the adoption of internet banking: a case study of commercial banks in Mauritius', World J. Sci. Technol. Sustain. Dev., vol. 9, no. 3, pp. 204-234, Jul. 2012.

[19] P. Malhotra, M. K. Normalini, and R. T., 'Factors affecting adoption of Internet Banking: A case study from India', Asia-Pacific J. Bus., vol. 5, no. November, pp. 13-24, 2014.

[20] E. G. Sarkane, D. Jurevičiene, V. Skvarciany, and J. Iljins, 'Internet banking adoption: case of Lithuania and Latvia', Int. J. Learn. Chang., vol. 9, no. 1, p. 46, 2017.

[21] Ahmed Em and Phin Gs, 'Factors Influencing the Adoption of Internet Banking in Malaysia', $J$. Internet Bank. Commer., vol. 21, no. 1, pp. 1-28, 2018.

[22] L. Vats and A. Maheshwari, 'Role of Customer's Trust on the Adoption of Internet Banking in Gwalior City', SSRN Electron. J., pp. 374-379, 2019.

[23] EUROSTAT, 'Individuals using the internet for internet banking - Eurostat'. [Online]. Available: https://ec.europa.eu/eurostat/en/web/products-datasets/-/TIN00099. [Accessed: 28-Jul-2019]. 